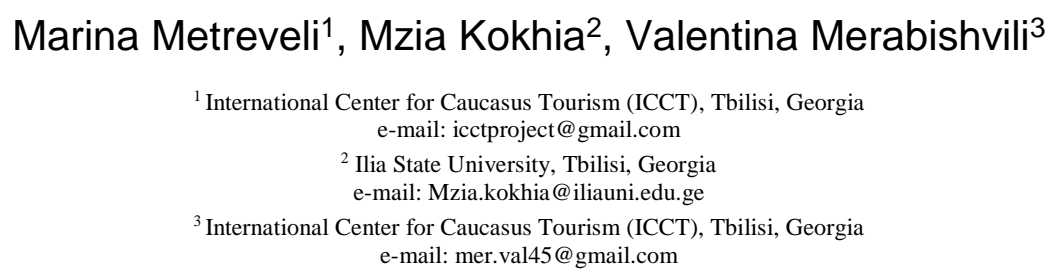

\title{
Tourism as the Principal Sphere for Economy Growth and Intercultural Relations in Georgia
}

JEL codes: Z32, M39, O40

Keywords: tourism industry, accommodation, travel agencies, ICCT

Summary. The study shows the involvement of private businesses in the tourism industry. It has covered the research of hotels, guesthouses and travel agencies, which was carried out in 2016 by The International Center for Caucasus Tourism (ICCT). The aim of the study was to determine the level of tourists' satisfaction during their visits to Georgia: whether they were happy or not (if not, why?) with services in Georgia, whether they liked the tourist sites and how they evaluated the potential of tourism situation. All materials and data are stored in the ICCT archives.

\section{Introduction}

Tourism is the international trend, on which the most part of the economy of Georgia depends. Therefore, each research aimed to study the tourism and its problems is very important. Based on the modern-day challenges foreign tourists are in search for new tourism destinations, i.e. looking for fresh and different impressions. From this standpoint Georgia has the potential of becoming a popular destination for tourists, as the country with such a small area. Georgia 
comprises the features characteristic both of Europe and Asia, due to the crossroads location between the two continents.

Georgia - a country no larger than Ireland - ranks in the world's top 12 for geographical diversity (Fig. 1). Set in the heart of the Greater Caucasus, it contains the highest mountains in Europe, semi deserts, subtropical wetlands with different climatic zones, national parks and forests, healing environment and mineral waters, a rich wine district and the Black Sea coast, much of it peppered with ancient stone towers, the beautiful and untouched nature. Add to this more species of animals and birds than in any European country and you have a walker's paradise (Nasmyth, 2013, p. 183).
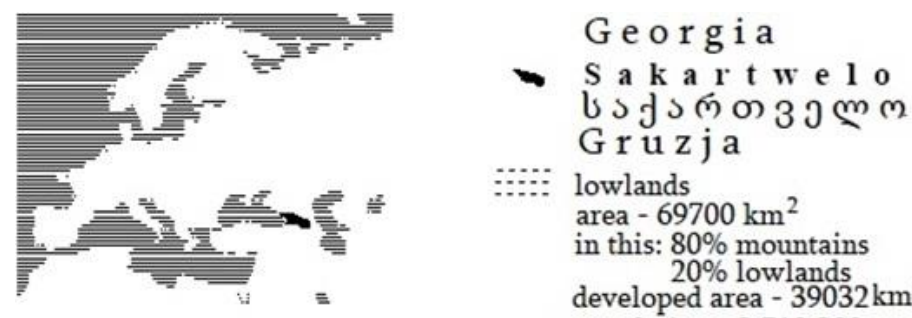

in this: $80 \%$ mountains

$20 \%$ lowlands
developed area $-39032 \mathrm{~km}^{2}$

population - 3718200 people

population density: average - 71 people $/ \mathrm{km}^{2}$

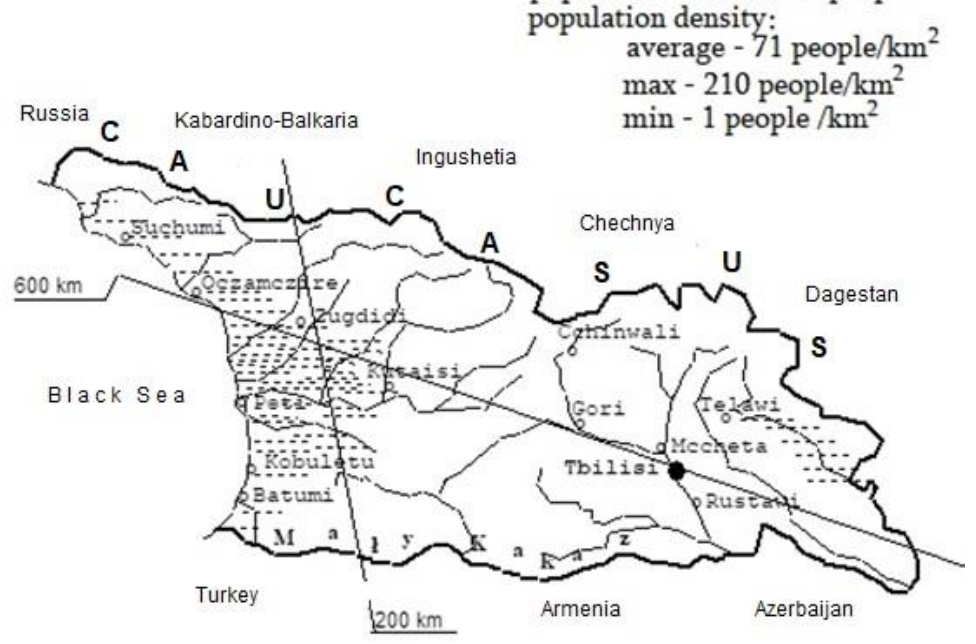

Figure 1. Scheme of Georgia

Source: Pirveli 2000, p. 20.

Additionally to the above mentioned attractions, Georgia is famous for its ancient history, multiethnic and rich culture, wine and cuisine and exceptional Georgian hospitality (Pirveli, 2000, pp. 5-30). That is why the majority of tourists visit Georgia not only to rest, but also to participate in recreational and educational events and to learn the local culture (Pirveli, 2010, pp. 7-17). Heritage in 
Georgia is almost synonymous with religious inheritance. Few countries in the world possess such an intensity of built religious patrimony in a small territory as the foundations of their heritage tourism sector as Georgia does.

Georgia is already an increasingly popular destination, but owing to its important religious history, the multitude of ancient churches and holy relics and the inseparable mix of religious and natural heritage escapes, the country has the potential to develop further in three areas of heritage tourism: domestic pilgrimage; international pilgrimage among Orthodox Christians from Eastern Europe and countries of the former USSR; and non-religious cultural tourists from all over the world (Metreveli, Timothy, 2010). Rural tourism is an old and a new phenomenon at the same time. The UNWTO has rated Rural Tourism as one of the fastest growing segments in the tourism industry, with an annual growth of $5 \%$ worldwide and representing 6\% of the world GDP (Dilys, Grieg-Gran, Schalken, 2001).

One of the problems of agro tourism is, that it is a poorly researched field of the tourist industry, as well as the lack of a specific definition of the tourism terms. At present there exist many definitions of "agro tourism." It is quite difficult to choose the most suitable definition for Agro tourism. Some authors consider agro tourism as one of the areas of eco-tourism (Volkov, 2012, pp. 30-38; Kundius, Chermjanina, 2011, 49-54). However, most of the popularity and rapid development of this type of tourism allow to consider agro tourism as an independent segment of the tourism industry.

Agro tourism essentially is environmentally friendly, but is fundamentally different in its objectives, the specifics of the organization and the nature of the ecotourism, though, in our opinion, both types of tourism motivation are very similar. Therefore, we believe that eco-tourism and agro-tourism are the elements of the concept of sustainable development of rural areas, implying use of natural resources and they can maintain their level also in future (Kosenchuk, Blinov, Novikov Yu, Rabkanova, 2015).

Successfully developing tourism finds its reflection in the development of main spheres of the country or of separate regions. To transform the structure of economics it is necessary to establish the broad network of tourism industry. It is a well-known fact that the mountainous regions are treasure of cultural heritage of Mankind. That is why mountainous regions including Georgia may be considered to be a sphere of stable development of special kinds of tourism such as: cultural tourism, ecotourism, agro tourism, sustainable rural tourism, youth and adventure tourism, wine tourism, business tourism, medical tourism.

The most active and busy period for tourist visits are from late spring to early fall. Traditionally, the number of tourists reaches its peak in August. September was noted as the most active season of the last year. However, the main problem of mountainous skiing resorts is its seasonal character. Ski resorts work 
and get income only for 100 days in a year, when they are obliged to spend money during the whole year. Georgia has a great opportunity in this direction as the slopes of the mountains are covered with snow from November till April (Gelashvili, 2012, pp. 85-89).

The focus on tourism development does not only contribute to creation of the infrastructure (roads, health facilities, sports, fitness centers) or necessity of preservation of historical, religious and archeological sites, local folklore, traditions, art and cuisine, culture, but also contributes to bringing the Nations closer and developing cooperation between them, as the increase of the number of tourists in the country promotes the establishment of friendly relations between the representatives of different countries and cultures. The example of this is close cooperation between Georgia and Turkey (Baramidze, 2012, pp. 187-189).

Nevertheless, awareness of the world about Georgia as a tourist destination is still low. Georgia is trying to maximize the level of knowledge and the awareness of the world community by means of marketing and PR activities. The country participates in International exhibitions; hosts tour operators and journalists, and also cooperates with such TV Channels as National Geographic, CNN, Travel Channel and others.

The National Tourism Agency often organizes Georgian Culture Days abroad.

\section{Research design and methodology}

The research had been conducted in the frames of the project "Tourism Paths of the Black Sea Region", implemented by ICCT in BSB-TOUR and was financed by the European Union through the Joint Operational Programme "Black Sea Basin 2007-2013". The study was carried out in 2016 in target cities and municipalities - covering 12 administrative units (Fig. 2): Ambrolauri, Tbilisi, Rustavi, Signagi, Gori, Kvareli, Batumi, Poti, Mestia, Mtskheta, Telavi, Kutaisi. About 500 respondents were questioned. The questionnaire for self-assessment of the infrastructure quality contains 31 inquiries; the vast majority of them are semi-open (the complete database is for inspection and is stored in the ICCT archiver; the questionnaire template is located at the end of the article, before the list of literature).

\footnotetext{
${ }^{1}$ At this point we want to give our special thanks to: GNTA for their support in conducting this research, Dr. N. Chakvetadze for her help to present the region's tourism potential assessment in Georgia and to all relevant Resource Centers and their employees, whose materials were used in the present work.
} 


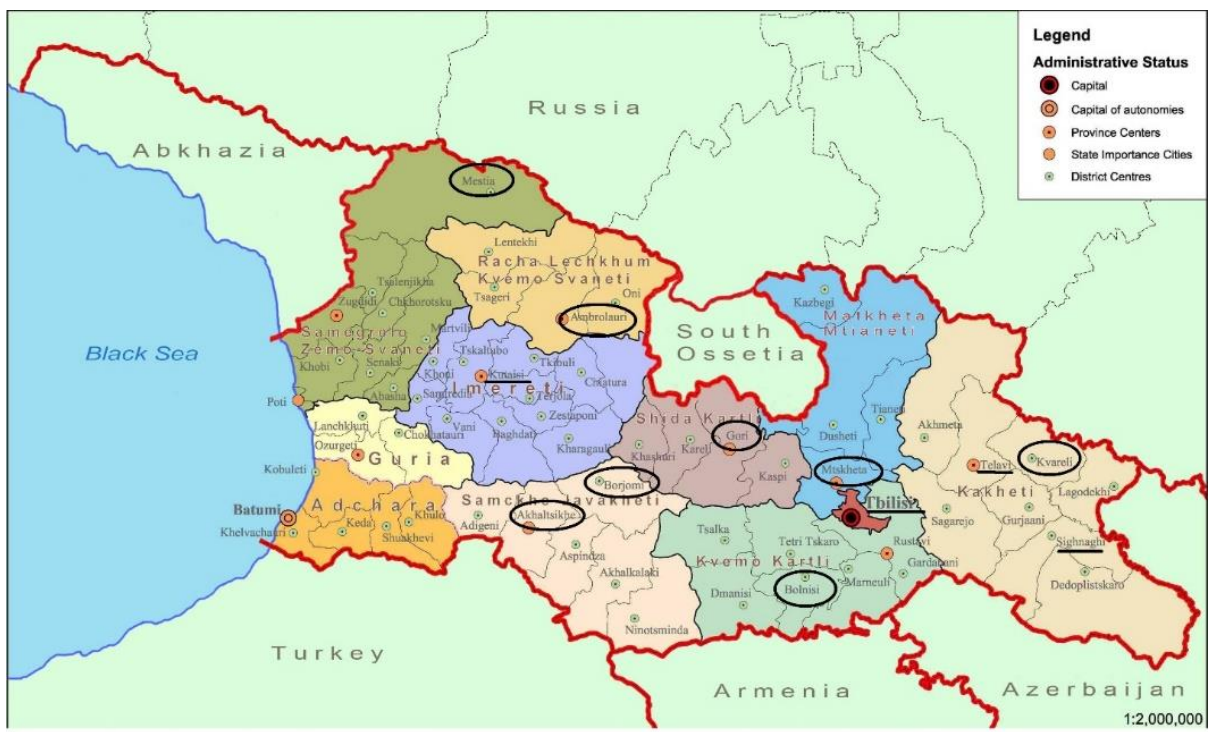

Area of the questionnaire survey conducted in 2016 by ICCT covers: Tbilisi (capital), Telavi (center of Kakheti), Kutaisi (center of Imereti), Signagi (town in Kakheti) and municipalities of Akhalcihe, Ambrolauri, Bolnisi, Borjomi, Gori, Kvareli, Mtskheta, Mestia. The total number of completed surveys is 488 .

Figure 2. Researched area

Source: development on the basis of Geo-Trip Advisor.

During the survey of the less tourist-active regions the family hotels of the private sector and tourist agents were questioned. The study revealed the problems they had faced in this process and what they mostly needed to promote the further development of tourism in their regions.

\section{Private Sectors in Tourism Industry}

Family hotels' owners who have been operating in the market for more than 8 years were interviewed. Despite the vast work experience none of them has been given the opportunity to expand the business that is why they can accommodate only 20 guests at a time. In their business they can employ not more than 2 persons. They describe their work as small-sized accommodation possibilities which are focused to create a cozy, warm and family atmosphere. Besides the accommodation their services include the provision of excursions in the region and the offer for tourists to involve them in the process of preparing traditional food and wine (Fig. 3). 


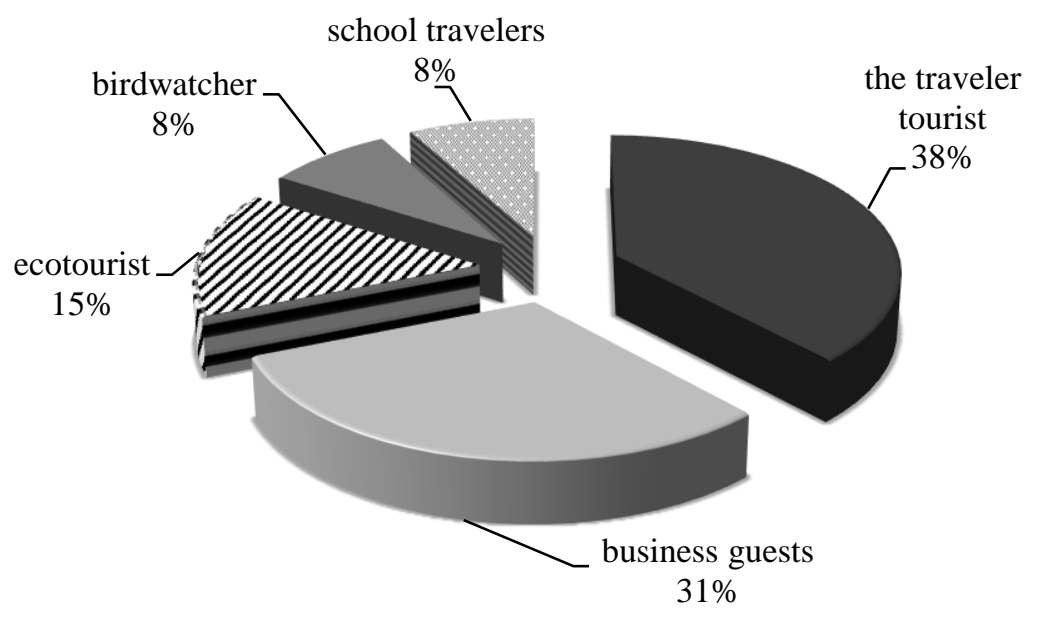

Figure 3. Types of tourists

Source: ICCT data base, 2016.

$56 \%$ of tourists using guest houses are Georgian tourists, while $44 \%$ are foreign tourists. Among these tourists most are 20-60 year-old traveler tourists figure 4 .

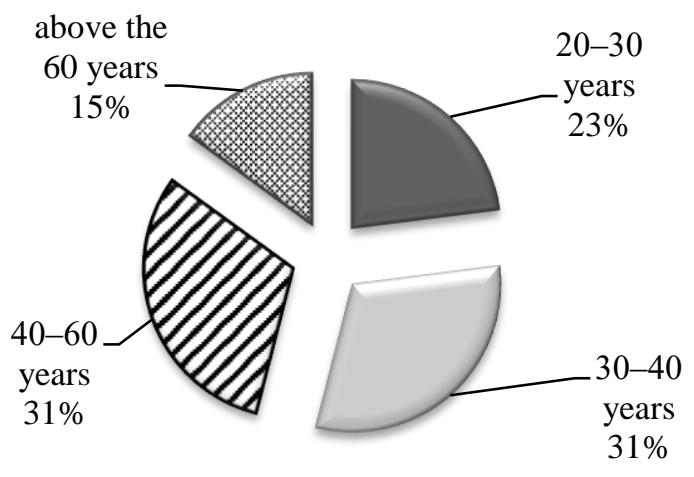

Figure 4. The age structure of tourists

Source: ICCT data base, 2016.

During the survey it was visible that tourist promotional materials for private tourist facilities and their representation are missing on the Internet, which is an integral part of modern tourism activities. The absolute majority of the hotels are not listed on international reservation portals, which makes it very difficult to find any information about them. In fact, they only exist due to social networking and unexpected tourists (Fig. 5-6). The region preserves its actual number of visitors 
through the amount of the tourists who got some recommendations from their friends and relatives to visit the region.

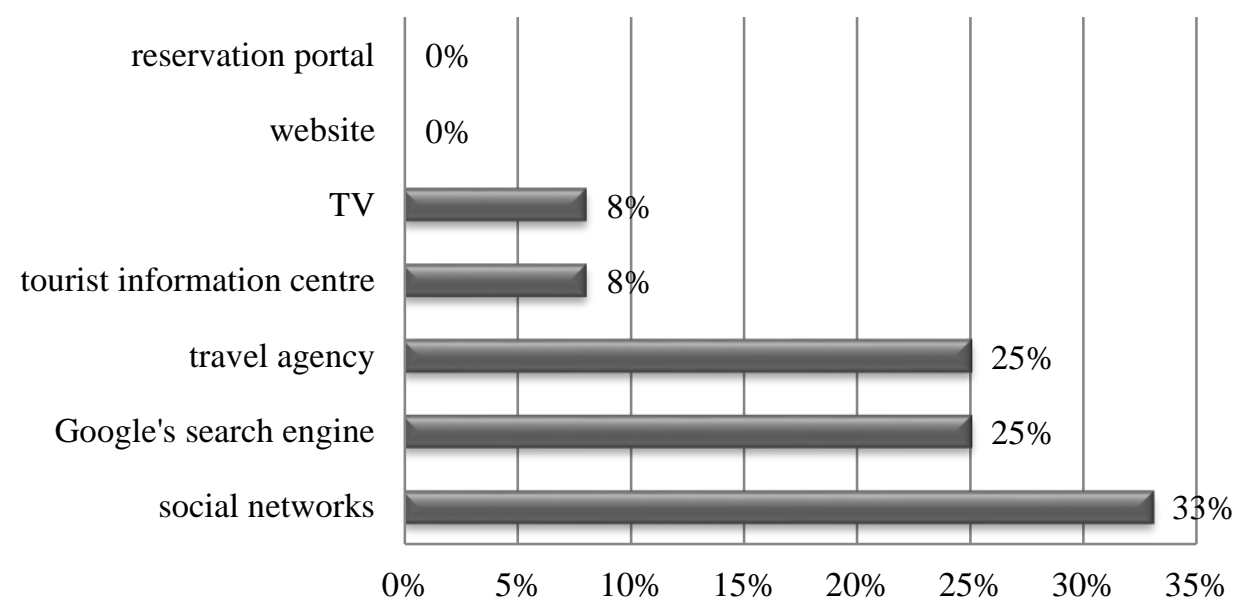

Figure 5. Information retrieval ways of tourists

Source: ICCT data base, 2016.

Printed information material

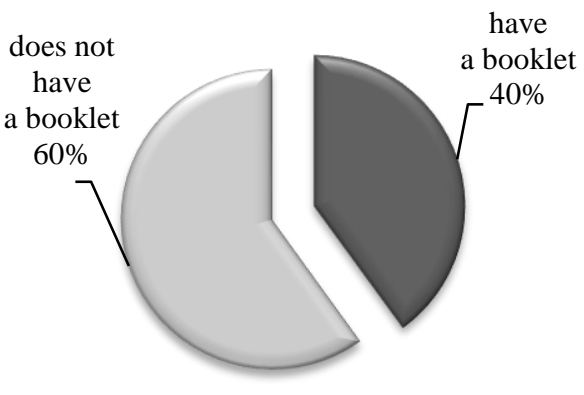

Among them who have a booklet

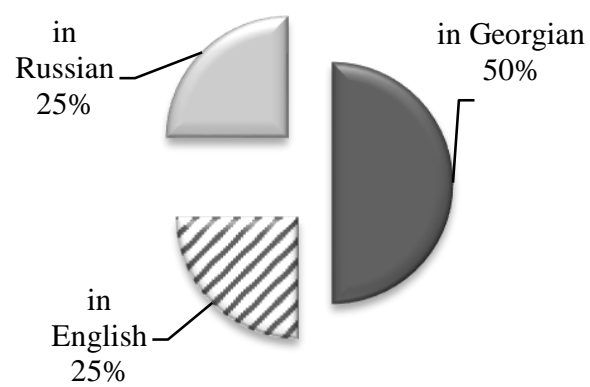

Figure 6. Provision information material for visitors

Source: ICCT data base, 2016.

Travel motivation, in most cases, is a sightseeing tour or business trip. Less share comes on other activities (Tab. 1).

The consumer segment consists mainly of Georgian tourists on vacation with a family, who usually stay at a guesthouse more than 2 weeks (Fig. 7). 
Family hotel consumers travel motivation

\begin{tabular}{|l|c|}
\hline \multicolumn{1}{|c|}{ Motivation } & Answer (\%) \\
\hline Visits to historical and cultural sights & 26 \\
\hline Business trips' purposes or a conference attendance & 21 \\
\hline Rest and relaxation in the countryside & 16 \\
\hline Participation in extreme sports activities & 16 \\
\hline Improvement of health and spa services & 5 \\
\hline Attendance of Entertainment Events & 5 \\
\hline Trade purposes & 5 \\
\hline Visiting of relatives and friends & 5 \\
\hline
\end{tabular}

Source: ICCT data base, 2016.

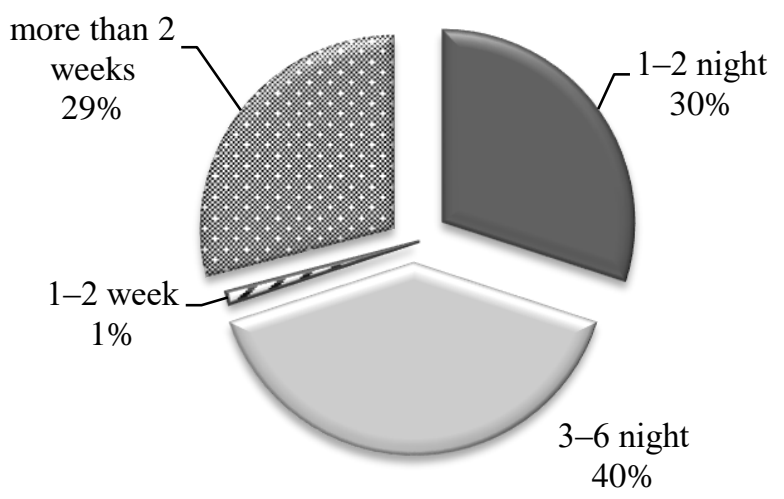

Figure 7. Tourists visit duration

Source: ICCT data base, 2016.

Family hotel businesses, as well as tourist agencies' services are dependent on seasons. According to the respondents, the main tourist season begins in April and lasts until mid-September. In contrast, tourists' agencies are active due to New Year celebrations. Proceeding from the questionnaire 50\% of family hotel services provide beds and breakfasts, $33 \%$ - beds and only $17 \%$ provide guests full board/full package. $80 \%$ of the surveyed private sector family hotel owners do not provide training courses for their employees. Only $20 \%$ of respondents said that they attended training sessions for managers organized by NGOs (nongovernmental organizations).

Small businesses are aware of the crucial importance to provide satisfactory service to the tourists and the sustainability in everything they do. They say that their guests are mainly permanent customers or visitors who got the recommendations from their permanent customers. 


\section{The region's tourism potential assessment of the private sector}

One of the most serious problems in the region is the migration of young people from their regions to the cities. The main reason identified was unemployment. Many picturesque resort places rich with natural resources are not rationally examined as the sites for economic growth and local people's engagement. This concerns the government and private sectors, both. The respondents believe and hopefully declare that the government will facilitate the development of business in the regions and will assist migrants to return.

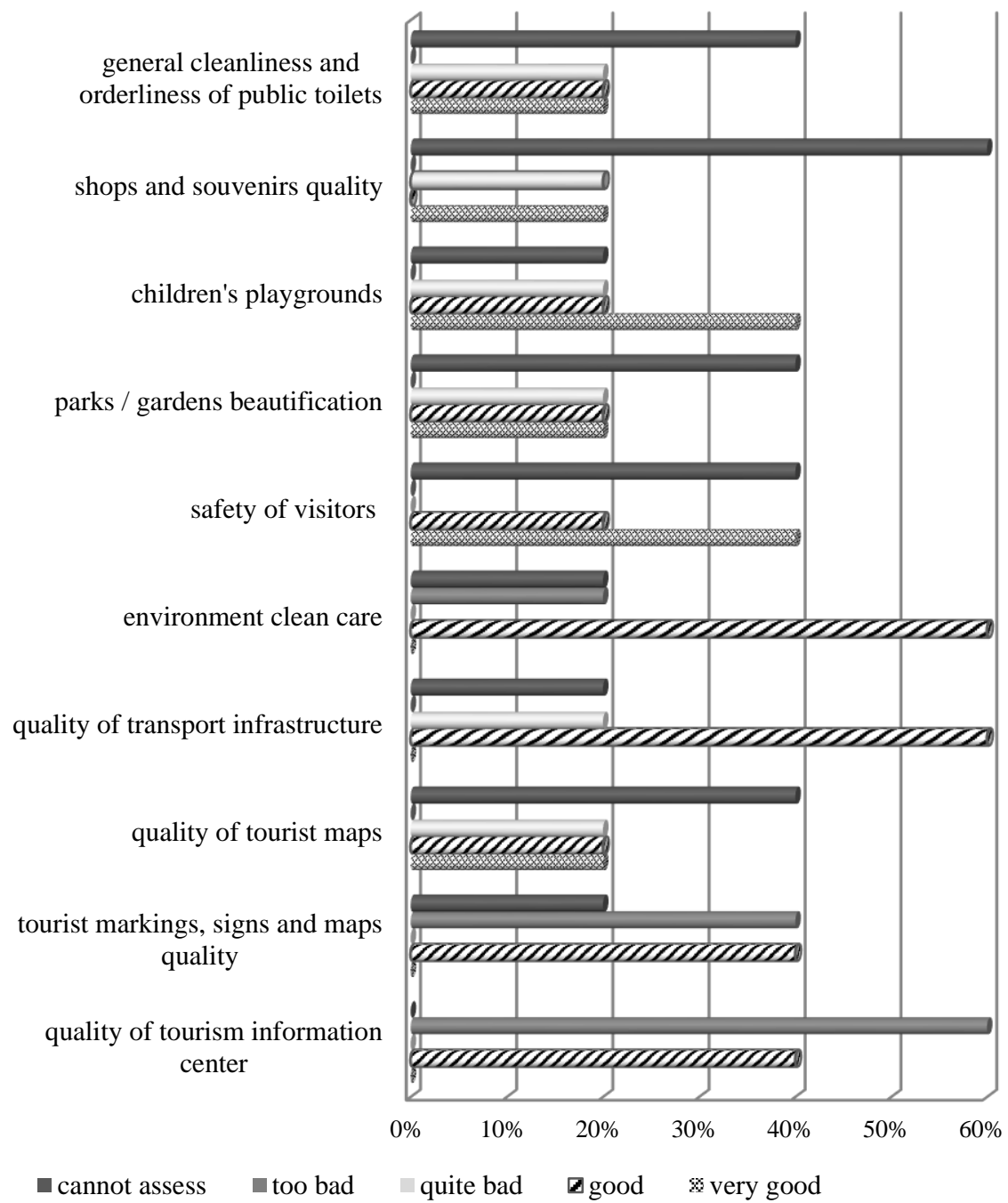

Figure 8. Self-assessment of the infrastructure quality

Source: ICCT data base, 2016. 
Special attention should be devoted to Sustainable Rural Tourism as the major part of Georgia belongs to rural areas and the most attractive tourism destinations are accumulated there. According to the respondents' opinions it will be preferable to arrange summer camps for school children and students that would promote the development of local tourism and arise an interest and curiosity in the youth to get acquainted with tourist resources.

The representatives working in the private sector express their regret on the lack of attention from the government which does not assist in providing enough tourist information to the regions. They noted that the regions were in need of many things necessary for the development of tourism in their regions. According to their opinion the government supports many other activities and advertisements on international and local levels, makes a lot of effort and spends money but they do not pay attention to the work performed by the private sector. They believe that all the regions have the potential for tourism development in Georgia, but only possession of historical and cultural resources is not enough. Attention should be drawn to the below given directions that will provide an extra motivation for local and foreign tourists to travel in different regions of Georgia (Tab. 2).

Table 2

Directions for Development

\begin{tabular}{|l|c|}
\hline \multicolumn{1}{|c|}{ Extra motivation directions } & Answer (\%) \\
\hline Restoration of historical monuments & 80 \\
\hline Promotion of rural tourism & 80 \\
\hline Organizing of Sports Tournaments & 80 \\
\hline Creation of Wine roads & 60 \\
\hline Promotion of Religious tourism & 60 \\
\hline Organizing of festivals and cultural activities & 60 \\
\hline Arrangement of Mountaineering paths for Climbers & 60 \\
\hline Arrangement of Entertainment & 60 \\
\hline Cycling Development & 45 \\
\hline Organizing of Spa, fitness Centers & 40 \\
\hline Improving of the people's qualification,employed in tourism & 40 \\
\hline
\end{tabular}

Source: ICCT data base, 2016.

\section{Conclusion}

The Presented research has shown that Georgia possesses a great potential for tourism development. The Analysis of the received results clearly revealed the problems existing in the country's tourism sector development. The increased interest of visitors to different regions of Georgia should be especially noted. Based on the foregoing state, the government must take into account the results of our research, i.e. to choose the relevant measures for tourism development as the principal sphere for economic growth and intercultural relations with an external world. Especially maximum of attention should be directed to sustainable rural 
tourism as the sources of livelihood improvement. Rural tourism has the potential to leave a positive impact on the economic environment and development of the study area, through increasing employment opportunities, increasing business diversity and activity, improving sales of goods and services, higher amounts collected in taxes, renovation and maintenance of cultural and historical heritage. This will make the local population take pride and care of the natural and historical values of the region, the development levels between regions start to equalize. Rural tourism development can play an important role in the diversification of the state tourist supply and in the creation of a more complex and colorful country image. On the other hand, rural tourism is not only the end, but the means to stimulate economic growth in the rural areas, to increase the viability of underdeveloped regions, and to improve the living standards of local populations. If rural tourism is to fulfill all these roles, it has to be developed in a way that ensures the long-term sustainability of the resources and that of the development process itself (Oruonye, 2013, pp. 1-6). Thus the motivation of rural recreation oneness with nature, clean air, organic food, change of conditions, a smaller number of people, the lack of population density, different lifestyle, schedule, and the culture of life, the opportunity to participate in agricultural work and horticultural care animals, participate in the harvest, and of course most importantly, low cost of vacation (Birjakov, 2000, p. 192).

It is generally considered that tourism in modern marketing system is one of the highly profitable direction of business for the state budget. Moreover, it is very important for improving the socio-economic status of the population, the growth of employment and reduction of migration. Thus, the development of tourism, the achievements of high level hospitality standards and their maintenance in the country should be acknowledged as the priority activities, which will be supported by the results of our research.

\section{Bibliography}

Baramidze, I. (2012). Development of Tourism in Georgia on the Model of the Autonomous Republic of Adjara and Shota Rustaveli State University. $1^{\text {st }}$ Winter Summit at the Anatolian Summit (WISAS): Collaborative Projects on Tourism Sports, Biodiversity and Global Changes.

Birjakov, M.В. (2000). Введение в туризм. Publishing House "Gerda".

Dilys, R., Grieg-Gran, M., Schalken, W. (2001). Getting the Lion's Share from Tourism: Private Sector-community Partnerships. IIED, NACOBTA

Gelashvili, T. (2012). Perspectives in the Development of Tourism in the Mountain Region. $1^{\text {st }}$ Winter Summit at the Anatolian Summit (WISAS): Collaborative Projects on Tourism, Sports, Bio Diversity and Global Changes.

Geo-Trip Advisor (2018). Retrieved from: https://geotripadvisor.wordpress.com/regions/.

ICCT data base (2016). International Center for Caucasus Tourism (ICCT). 7, M. Lebanidze Str., 0119, Tbilisi, Georgia. 
Kosenchuk, O.V., Blinov, O.A., Novikov, Yu.I., Rabkanova, M.A. (2015). Рабканова M.A. Понятие Агротуризма в Теории и Практике Управления Сельскими Территориями. Современные проблемы науки и образования, 2 (2).

Kundius, V.A., Chermjanina, V.V. (2011). Проблемы и перспективы агротуризма в регионе. Agrarian Russia, 2, 49-54.

Metreveli, M. Timothy, D.J. (2010). Religious Heritage and Emerging Tourism in the Republic of Georgia. Journal of Heritage Tourism, 5 (3), 237-244.

Nasmyth, P. (2013). Walking in the Caucasus Georgia Including Flora and fauna. Mta Publications.

Oruonye, E.D. (2013). The Challenges of Rural Tourism Development in Nigeria: A Case of Yorro lga, Taraba State Nigeria. International Journal of Social Sciences Arts and Humanities, 1 (1), 1-6.

Pirveli, M. (2000). Potencjalne walory turystyczne Gruzji. Turyzm, 10 (2), 5-30.

Pirveli, M. (2010). Gruziński turyzm - niewykorzystany potencjał. In: M. Dutkowski (ed.), Problemy turystyki i rekreacji. Vol. 3. (pp. 7-17). Szczecin: Oficyna In Plus.

Volkov, S.K. (2012). Сельский туризм в РФ: тенденции и перспективы развития. Экономика, предпринимательство и право, 6 (17), 30-38.

\section{Turystyka jako główna sfera wzrostu gospodarczego i stosunków międzykulturowych w Gruzji}

Słowa kluczowe: przemysł turystyczny, zakwaterowanie, biura podróży, ICCT

Streszczenie. W artykule przedstawiono stopień zaangażowania prywatnych firm w aktywność branży turystycznej. Badaniami objęto hotele, pensjonaty i biura podróży. Ich celem było określenie poziomu satysfakcji turystów podczas ich wizyt w Gruzji: czy byli zadowoleni, czy nie (jeśli nie, to dlaczego?) usługami w Gruzji? Czy podobały im się miejsca turystyczne i jak oceniają potencjał warunków turystycznych. Prace badawcze przeprowadzono w 2016 roku przez międzynarodowe centrum turystyki kaukaskiej (ICCT). Wszystkie materiały i dane przechowywane są w archiwum ICCT.

\section{Citation}

Metreveli, M., Kokhia, M., Merabishvili, V. (2018). Tourism as the Principal Sphere for Economy Growth and Intercultural Relations in Georgia. Marketing i Zarzadzanie, 4 (54), 35-46. DOI: 10.18276/miz.2018.54-03. 